\title{
PELATIHAN PEMBUATAN MEDIA FX DRAW BAGI GURU SMP MUHAMMADIAH MALANG
}

\section{TRAINING OF MAKING FX DRAW MEDIA FOR MUHAMMADIYAH JUNIOR HIGH SCHOOL TEACHERS IN MALANG}

\author{
D P Utomo'ia, S Inganah'
}

\author{
${ }^{1}$ Program Studi Pendidikan Matematika, Universitas Muhammadiyah Malang. Jalan \\ Raya Tlogomas No 246 Tlogomas, Babatan, Tegalgondo, Kec Lowokwaru, Kota Malang, \\ Jawa Timur 65144 \\ a Korespondensi:Dwi Priyo Utomo, E-mail: dwi.proyo.umm@gmail.com
}

(Diterima: 28-09-2019; Ditelaah: 29-09-2019; Disetujui: 30-10-2020)

\begin{abstract}
The aim of this service is to overcome the problem of teacher professional competence, especially in making innovative learning media especially using FX Draw. The service method used is 1). workshop on learning media, 2). assistance in making Learning Media, 3). testing the FX Draw learning media, 4). reflection and evaluation. The activity has been carried out and is in accordance with the initial plan of training and assistance in making learning media using the proposed FX Draw. The results of reflection and evaluation show that participants are already skilled in using FX Draw. The results of filling out the questionnaire through the Google form showed that the participants were greatly helped in making LKPD more interesting for students, and made it easier for teachers to make mathematical objects (such as in geometry, quadratic functions, graphics, flat shapes, building spaces, etc.). The participants also still need a lot of training in using mathematicsbased applications to assist in making mathematics learning media more interesting.
\end{abstract}

Keywords: media, fx draw, teachers.

\begin{abstract}
ABSTRAK
Tujuan pengabdian ini adalah untuk mengatasi masalah kompetensi profesional guru, khususnya dalam pembuatan media pembelajaran inovatif khususnya menggunakan FX Draw. Metode pengabdian yang digunakan adalah 1). workshop tentang media pembelajaran, 2). pendampingan pembuatan Media Pembelajaran, 3). uji coba media pembelajaran FX Draw, 4). refleksi dan evaluasi. Kegiatan tersebut telah terlaksana dan sesuai dengan rencana awal pelatihan dan pendampingan pembuatan media pembelajaran menggunakan FX Draw yang telah diajukan. Hasil refleksi dan evaluasi menunjukkan bahwa peserta sudah terampil menggunakan FX Draw. Hasil pengisian angket melalui Google form terlihat bahwa para peserta sangat terbantu dalam pembuatan LKPD yang lebih menarik untuk peserta didik, dan mempermudah guru dalam membuat objek-objek matematika (seperti dalam geometri, fungsi kuadrat, grafik, bangun datar, bangun ruang, dll). Para peserta juga masih membutuhkan banyak pelatihan-pelatihan menggunakan aplikasi berbasis matematika guna membantu dalam pembuatan media pembelajaran matematika yang lebih menarik lagi.
\end{abstract}


Kata Kunci: pelatihan, fx draw, guru

\begin{abstract}
Utomo, D.P., dan Inganah, S. (2019). Pelatihan pembuatan Media Fx Draw Bagi Guru SMP Muhammadiyah Malang. Jurnal Qardhul Hasan : Media Pengabdian kepada Masyarakat, 5(2), 97100.
\end{abstract}

\section{PENDAHULUAN}

Pada masa kini pengetahuan matematika sangat penting bagi siswa dalam kehidupan sehari-hari. Guru sebagai fasilitator di kelas dituntut untuk terus berinovasi agar siswa lebih termotivasi dalam belajar khususnya belajar matematika, sehingga bukan hanya siswa saja yang terus belajar melainkan guru juga harus terus belajar untuk mengembangkan diri disetiap saat dan dimanapun. Karena dari guru yang terus belajar dan berkarya akan muncul generasi pembelajar sepanjang hayat yang terus menerus berkontribusi pada masyarakat dan lingkungannya.

Saat ini perkembangan ilmu pengetahuan dan teknologi menuntut guru untuk belajar beradaptasi dengan hal-hal baru yang berlaku saat ini. Karena bagi seorang guru, kebutuhan akan penguasaan teknologi merupakan hal harus dipenuhi guna mendukung kegiatan pembelajaran (Afifah, 2017). Bukan hanya itu, karakter peserta didik yang berbeda dari generasi ke generasi sangat berpengaruh dan menjadi tantangan tersendiri bagi seorang guru. Oleh karena itu, guru harus beradaptasi dan terus menerus mengembangkan diri terhadap perkembangan ilmu pengetahuan dan teknologi.

Perkembangan teknologi saat ini yang tidak dapat dipungkiri adalah adanya komputer. Hampir seluruh generasi muda saat ini khususnya siswa SMP dapat menggunakan komputer. Bahkan dalam segala hal dapat dilakukan dengan menggunakan komputer, tidak terkecuali dalam bidang pendidikan terutama pembelajaran matematika. Salah satu manfaat komputer dalam berbagai bidang adalah dapat meninggkatkan kinerja (Karimah,dkk, 2017) Sehingga penggunaan komputer sebagai alat atau media pembelajaran matematika akan sangat membantu siswa untuk lebih termotivasi dalam belajar. Karena media pembelajaran sejati adalah sebagai alat bantu yang dapat dijadikan penyalur pesan guna mencapai tujuan pembelajaran (Smaldino,dkk, 2008 \& Djamarah, 2010). Sebagai contoh media pembelajaran yang dapat diaplikasikan didalam komputer adalah FX Draw.

FX Draw merupakan salah satu media pembelajaran dibidang matematika. FX Draw merupakan aplikasi ilmu pengetahuan dan teknologi kekinian. FX Draw adalah program dengan beragam fasilitasnya dapat dimanfaatkan sebagai media pembelajaran matematika untuk mendemonstrasikan atau memvisualisasikan konsep-konsep matematis terutama untuk menggambar diagram dan bangun geometri 2 dimensi. Hal tesebut sejalan dengan penelitian Anggraeni (2016) yaitu FX Draw membantu siswa lebih mudah mengidentifikasi sifatsifat dua bangun datar sebangun apabila dibandingan dengan menggunakan alat ukur manual. FX Draw adalah software matematika buatan efofex. Software ini sangat cocok buat guru ataupun siswa yang ingin membuat diagram matematika dua dimensi dengan cepat dan akurat, serta dengan mudah untuk ditempelkan ke MS Word. kelebihan dari Software FX Draw ini adalah dapat terintegrasi dengan Microsoft Word 2000, 2003, 2007, 2010. Sehingga ketika kita membuka Microsoft Word yang sudah terpasang program FX Draw maka secara otomatis akan tampil pada baris menunya. software ini juga bersifat freeware sehingga dapat mengunduhnya dengan mudah di internet.

Berdasarkan wawancara dengan guruguru matematika SMP, sangat jarang mereka menggunakan media FX Draw. Dengan kondisi seperti ini, sangat diperlukan suatu kegiatan yang dapat 
membantu memecahkan masalah tersebut. Pendampingan Pembuatan Media Pembelajaran dengan FX Draw bagi Guru SMP Muhammadiyah Se-Kota Malang merupakan salah satu kegiatan yang mencoba menjawab sekaligus mengatasi kendala yang ada.

\section{MATERI DAN METODE}

Adapun kegiatan pada pengabdian ini, dalam bentuk pelatihan dan pendampingan. Kegiatan pelatihan dan pendampingan pembuatan media pembelajaran menggunakan aplikasi FX Draw bagi Guru SMP Muhammadiyah se-kota Malang, didesain melalui empat kegiatan. Yaitu; 1) Workshop tentang Media Pembelajaran, 2) Pendampingan Pembuatan Media Pembelajaran, 3) Uji coba Media Pembelajaran FX Draw, 4) Refleksi dan Evaluasi dengan draft kegiatan pelatihan sebagai berikut.

Tabel 1. Kegiatan

\begin{tabular}{|c|c|c|}
\hline No & $\begin{array}{c}\text { Waktu } \\
\text { Pelaksanaan } \\
\end{array}$ & Kegiatan \\
\hline 1 & $\begin{array}{c}13.30- \\
13.45\end{array}$ & Pembukaan \\
\hline \multirow[t]{2}{*}{2} & $\begin{array}{c}13.45- \\
15.00\end{array}$ & $\begin{array}{l}\text { Materi Penggunaan } F X- \\
\text { Draw dalam pembuatan } \\
\text { Media Pembelajaran } \\
\text { Matematika }\end{array}$ \\
\hline & $\begin{array}{c}15.00- \\
16.15\end{array}$ & $\begin{array}{l}\text { Praktek Pembuatan } \\
\text { Media Pembelajaran } \\
\text { Matematika }\end{array}$ \\
\hline 3 & $\begin{array}{c}16.15- \\
16.30\end{array}$ & Penutupan \\
\hline
\end{tabular}

Pembuatan dan uji coba media pembelajaran matematika menggunakan FX Draw ini telah dilakukan dan dikirimkan hasil uji coba FX Draw secara kolektif selama satu minggu setelah selesai dilaksanakannya pelatihan pembuatan media pembelajaran menggunakan FX Draw.

Kegiatan pelatihan dan pendampingan pembuatan media pembelajaran menggunakan FX Draw bagi Guru SMP
Muhammadiyah se-kota Malang di Kota Malang ini didesain melalui empat kegiatan. Keempat kegiatan tersebut akan dijelaskan sebagai berikut. (1) Workshop tentang Media Pembelajaran. Pada kegiatan pertama dilakukan workshop tentang media pembelajaran, guruguru/peserta diberi materi tentang media, jenis-jenis media, tahapan pembuatan media. Hal ini sebagai salah satu bekal bagi peningkatan profesionalisme guru. Pada akhir kegiatan ini diharapkan peserta lebih memahami dan dapat mengaplikasikan media pembelajaran dengan menggunakan FX Draw untuk membuat media yang lebih menarik siswa di kelas. (2) Pendampingan Pembuatan Media Pembelajaran. Implementasi dari kegiatan pertama, kemudian diterapkan dengan membuat media pembelajaran menggunakan FX Draw. Aktivitas pendampingan dilakukan secara intensif dan fleksibel melalui email. (3) Uji coba Media Pembelajaran FX Draw. Kegiatan pada tahap ini, yaitu uji coba hasil produk yang diperoleh pada kegiatan kedua. Guru melakukan uji coba media pembelajaran FX Draw di kelas. (4) Refleksi dan Evaluasi. Kegiatan terakhir adalah refleksi dan evaluasi. Proses kegiatan ini dilakukan melalui pengisian form dengan memanfaatkan Aplikasi Google form.

\section{HASIL DAN PEMBAHASAN}

Workshop tentang pelatihan dan pendampingan pembuatan media pembelajaran menggunakan FX Draw ini dilaksanakan pada hari Rabu, 4 September 2019 pukul 13.00 WIB sampai selesai yang bertempat di ruang 3.03 lantai 3 GKB 4 . Materi yang disampaikan pada tahap ini berkaitan tentang penggunaan FX-Draw dalam pembuatan media pembelajaran matematika dan praktek pembuatan media pembelajaran matematika menggunakan FX-Draw yang disampaikan oleh dua narasumber. Pelatihan ini diikuti oleh guruguru SMP Muhammadiyah Se-Kota dan Kabupaten Malang. Adapun rincian lengkap peserta pendampingan yang terdiri dari 
guru-guru SMP Muhammadiyah Se-Kota dan Kab. Malang adalah sebagai berikut.

\section{KESIMPULAN}

Perekonomian masyarakat Desa Padamulya masih perlu untuk ditingkatkan. Walaupun perekonomian masyarakat Desa Padamulya masih dapat dikatakan standar, tetapi tingkat perekonomian Desa Padamulya tersebut dapat ditingkatkan melalui kegiatan ekonomi kreatig melalui inovasi produk. Dapat dilihat dari segi geografis kampung Goleah berada pada kawasan yang stategis dikelilingi oleh beberapa taman hiburan keluarga seperti Curug Citambur, dan Wisata Pohon Pinus. Hal ini dapat dimanfaatkan untuk menggali potensi masyarakat di bidang ekonomi dan dengan adanya kegiatan pelatihan inovasi produk olahan singkong ini diharapkan dapat menjadi wadah bagi masyarakat untuk bisa memasarkannya sebagai sebuah oleh-oleh atau buah tangan khas Desa Padamulya.

\section{Saran}

Sesuai angket Google form yang telah dibagikan melalui media sosial para peserta workshop, terlihat bahwa guru masih membutuhkan banyak pelatihan tentang aplikasi media terkini untuk dapat memudahkan dan menarik perhatian siswa dalam proses pembelajaran matematika, antara lain; maple, geogebra, i-spring, delphi, dan edmodo.

\section{DAFTAR PUSTAKA}

Afifah, Ani. 2017. Pembelajaran matematika dengan Memanfaatkan Formulator Tarsia. Jurnal Didaktik Matematika, Vol.4, No.2, Hal: 152-159

Anggraeni, Setyaning Dewi. 2016. Penggunaan FX Draw untuk Memahamkan Konsep Kesebangunan melalui Metode Penemuan Terbimbing pada Siswa kelas IX SMPN 23 Malang. Tesis. Program Studi Pendidikan Matematika. Pascasarjana Universitas Negeri Malang

Djamarah, S., Zain, A. 2010. Strategi Belajar Mengajar. Jakarta: PT Rineka Cipta

Karimah, AL Anisah., Rusdi., Fachruddin, M. 2017. Efektifitas Media Pembelajaran Matematika Menggunakan Software Anime Berbasis Multimedia Interaktif Model Tutorial pada Materi Garis dan Sudut untuk Siswa SMP/MTS Kelas VII. Jurnal Penelitian Pembelajaran Matematika Sekolah (JP2MS), Vol.1, No.1, Hal:9-13

Smaldino, Sharon., Lowther, Deborah \& Russell, James. 2008. Instructional Technology \& Media for Learning (terjemahan). Jakarta: Kencana Prenada Media. 